\title{
PEMBERDAYAAN KELOMPOK MASYARAKAT PERAJIN BAMBU DI DESA SIRKANDI PURWAREJA KLAMPOK BANJARNEGARA
}

\author{
EMPOWERING GROUP OF COMMUNITY BAMBOO SOCIETY \\ IN THE VILLAGE OF PURWAREJA KLAMPOK BANJARNEGARA \\ ${ }^{1)}$ Sarno \\ ${ }^{1)}$ Program Studi Agroteknologi, Politeknik Banjarnegara \\ Jl. Raya Madukara Km. 2 Kenteng Banjarnegara, Jawa Tengah \\ email: abisarno1@gmail.com
}

\begin{abstract}
ABSTRAK
Kegiatan pemberdayaan kelompok masyarakat UMKM perajin bambu dilaksanakan di Desa Sirkandi Kecamatan Purwareja Klampok Kabupaten Banjarnegara.Desa Sirkandi memiliki potensi jumlah perajin bambu yang tergabung dalam UMKM paling banyak di Kecamatan Purwareja Klampok Banjarnegara.Tujuan kegiatan diarahkan pada kelompok masyarakat UMKM Perajin Bambu Arrohman terutama dalam hal peningkatan produksi dan pendapatan.Pengembangan industri kreatif berbasis potensi desa berupa diversifikasi produk kerajinan bambu seperti piti dan tampah berkualitas dan marketable.Metode yang digunakan dalam kegiatan ini yaitu pendidikan masyarakat dan pelatihan yang ditujukan kepada kelompok UMKM perajin bambu Arrohman.Pendidikan masyarakat dilakukan melalui kegiatan penyuluhan tentang pengembangan industri kreatif bambu, diversifikasi produk dan strategi pemasaran produk kerajinan bambu.Pelatihan berupa demonstrasi langsung atau praktik diversifikasi produk kerajinan bambu berupa piti dan tampah bambu. Hasil kegiatan berupa peningkatan pengetahuan UMKM tentang pemanfaatan potensi bambu sebagai bahan kerajinan, keterampilan UMKM meningkat melalui kegiatan pelatihan keterampilan penerapan strategi diversifikasi dan pemasaran produk, diversifikasi produk kerajinan bambu yang dihasilkan oleh UMKM berupa produk tampah bambu, dan penerapan standarisasi pada tahapan produksi.
\end{abstract}

Kata Kunci: Pemberdayaan, Kelompok Masyarakat, Perajin Bambu, Banjarnegara

\begin{abstract}
Empowerment activities of community groups of bamboo craftsmen SMEs implemented in the Village Sirkandi Purwareja Klampok Banjarnegara District. Sirkandi village has the potential of the number of bamboo crafters who are incorporated in the most SMEs in Purwareja Klampok Banjarnegara. The purpose of the activity is directed to community groups of SMEs Arrohman Bamboo Crafters, especially in terms of increasing production and income. The development of creative industries based on the potential of the villages in the form of diversification of bamboo handicraft products such as piti and tampah quality and marketable. The method used in this activity is community education and training aimed at the group of UMKM Arrohman bamboo crafters. Community education is conducted through extension activities on the development of bamboo's creative industry, product diversification and marketing strategy of bamboo handicraft products. Training in the form of direct demonstration or diversification of bamboo handicraft products in the form of piti and tampah bamboo. The result of the activity is to increase the knowledge of UMKM about the utilization of bamboo potential as a craft material, the skills of UMKM increased through skill training activity of diversification strategy and product marketing, bamboo handicraft product diversification produced by UMKM in the form of bamboo tampah products, and standardization application at production stage.
\end{abstract}


Keywords : Empowerment, Community Groups, Bamboo Craftsmen, Banjarnegara

\section{PENDAHULUAN}

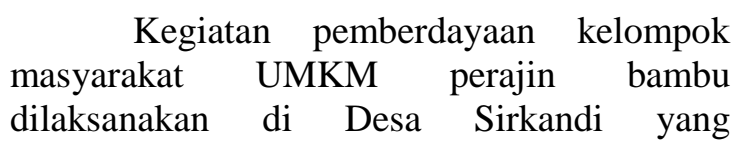
merupakan salah satu desa di Kecamatan Purwareja Klampok Kabupaten Banjarnegara. Memiliki luas wilayah paling luas yaitu 579,57 hektar atau sekitar 27,29\% dari luas kecamatan. Memiliki jumlah Dusun 5, jumlah RW 5, dan jumlah RT sebanyak 33. Desa Sirkandi terletak di $7,48^{\circ}$ LS $109,46^{\circ}$ BT. Ketinggian tempat mencapai 108 mdpl dan jarak ke ibukota kecamatan mencapai $4 \mathrm{~km}$. Desa Sirkandi memiliki jumlah penduduk sebanyak 6.154 jiwa dengan jumlah penduduk laki-laki sebanyak 3.070 jiwa dan penduduk perempuan sebanyak 3.084 jiwa.. Luas lahan sawah sekitar $0,50 \mathrm{~km}^{2}$, bukan sawah 1,71 $\mathrm{km}^{2}$ dan bukan lahan pertanian mencapai 3,58 $\mathrm{km}^{2}$. Mayoritas masyarakat Desa Sirkandi bermata pencaharian sebagai perajin bambu.Hal tersebut didukung oleh adanya potensi jumlah tanaman kehutanan berupa tanaman bambu mencapai 4.088 (BPS Kabupaten Banjarnegara, 2017).

Keberadaan jumlah UMKM perajin bambu Arrohman di Desa Sirkandi mencapai 107 orang tersebar di dua dusun yaitu Beji dan Kereyek.Jenis produk kerajinan tangan yang dihasilkan masih menjadi icon dari dulu sampai sekarang adalah piti. Piti merupakan jenis kerajinan tangan yang terbuat dari bambu dan biasanya digunakan sebagai wadah/kemasan produk makanan seperti getuk goreng, tempat nasi, dan lain-lain. Kelompok masyarakat yang tergabung dalam perajin piti bambu mampu menghasilkan produksi piti bambu sebanyak 3.600 buah dalam sehari atau sekitar 108.000 buah/bulan. Kebutuhan akan bahan baku bambu 1 batang/orang dapat menghasilkan sekitar 180 buah piti dalam sehari, sehingga kebutuhan pasokan bahan baku bambu sekitar 20 batang/hari dengan harga Rp 5.000,-/batang. Harga jual produk piti bambu sekitar Rp 150,-/buah di pedagang pengumpul. Jika dihitung maka penerimaan yang diperoleh kelompok perajin piti bambu sekitar Rp 27.000,-/orang/hari atau sekitar Rp 810.000,-/orang/bulan (Sarno, dkk, 2014). Permasalahan klasik yang masih terjadi pada kelompok masyarakat perajin bambu secara garis besar dapat dijelaskan bahwa belum adanya kegiatan diversifikasi produk kerajinan tangan bambu.Artinya dari dahulu sampai sekarang masih turun temurun membuat produk kerajinan tangan hanya jenis piti bambu.Belum mengenal bentuk/jenis kerajinan bambu lainnya.Padahal jika dikembangkan menjadi bentuk/jenis kerajinan tangan bambu lainnya dapat meningkatkan pendapatan masyarakat dan tentu saja memperluas jaringan pemasaran yang selama ini menjadi masalah utama.

Potensi sumberdaya alam berupa jumlah tanaman bambu yang melimpah di Desa Sirkandi baru dimanfaatkan oleh para kelompok masyarakat perajin bambu sebagai produk piti bambu dan sebagian lagi dijual.Keahlian secara turun temurun terus dilestarikan oleh masyarakat.Upaya pemberian pemahaman kepada masyarakat perajin bambu menjadi salah satu upaya yang perlu dilakukan dalam rangka mendukung peningkatan produksi dan pendapatan. Selain itu ditujukan dalam rangka mendukung pengembangan 
kemandirian dan keberlanjutan usaha industry kreatif berbasis potensi desa.Persiapan kegiatan pemberdayaan kelompok masyarakat perajin bambu yang dilakukan adalah dengan membuat perencanaan, pengorganisasian sampai pada kegiatan monitoring dan evaluasi kegiatan pendidikan dan pelatihan diversifikasi produk kerajinan bambu menjadi produk piti dan tampah bambu.Kegiatan pendidikan dan pelatihan tersebut berbasis pada kelompok masyarakat melalui penerapan standart operational procedur (SOP) dan pengawasan sistem mutu pada tahap produksi piti dan tampah bambu. Selain itu juga dilakukan penerapan standart sanitation operational procedure (SSOP) pada tahap proses produksi piti dan tampah bambu.

Pengembangan usaha mikro kecil pada kelompok masyarakat bisa menjadi salah satu jalan keluar untuk menumbuhkan daya saing di Indonesia menjadi lebih baik.Tentu saja upaya tersebut dilakukan dengan terus meningkatkan dan melakukan pendampingan terhadap kinerja usaha agar tetap mampu bersaing pada era perdagangan bebas.Upaya tersebut salah satunya dengan meningkatkan kualitas atau mutu produk yang dihasilkan oleh usaha mikro kecil sesuai dengan latar belakang usaha yang digelutinya (Ardiansyah, 2011). Mengingat daya saing usaha mikro kecil pada kelompok masyarakatdi Indonesia masih sangat rendah sekitar 3,5 dari skor 1-10 dibandingkan negara-negara ASEAN. Lemahnya daya saing tersebut merupakan salah satu permasalahan yang harus segera dipecahkan demi kemajuan dan kesejahteraan Indonesia (Bappenas, 2011). Kemampuan usaha mikro kecil pada kelompok masyarakatdi Indonesia untuk melakukan proses pengembanganjuga kurang berjalan. Ini merupakan cerminan bahwa wirausahawan di Indonesia masih kurang inovatif.Mengingat rendahnya daya saing tersebut maka harus dicarikan jalan keluar sehingga daya saing usaha di Indonesia menjadi lebih baik.
Salah satu upaya peningkatan daya saing usaha kelompok masyarakat dapat dilakukan melalui penerapan strategi bauran pemasaran atau marketting mix strategy.Hal tersebut bertujuan membuka peluang pasar atau pemasaran antar daerah/wilayah.Dengan adanya kegiatan tersebut diharapkan dapat meningkatkan kualitas dan kuantitas produk kerajinan piti bambu yang selama ini masih tersekat-sekat wilayah pasarnya dan belum menjangkau ke luar daerah.Secara umum penerapan sistem kelembagaan pemasaran kelompok masyarakat perajinbambu di Desa Sirkandi masih tergolong lemah. Lemahnya sistem kelembagaan pemasaran tersebut dikarenakan kelembagaan pemasaran yang terlibat belum efisien. Menurut Syahza (2007), suatu sistem pemasaran yang efisien harus mampu dan memenuhi dua persyaratan yaitu: (1) mengumpulkan hasil pertanian dari produsen ke konsumen dengan biaya serendah-rendahnya, (2) mampu mendistribusikan sistem pembagian balas jasa yang adil dari keseluruhan harga konsumen akhir kepada semua pihak yang terlibat mulai dari kegiatan produksi hingga pemasaran. Kelembagaan pemasaran seringkali memiliki perbedaan terutama menyangkut komoditas dan daerah. Namun secara umum kelembagaan yang terlibat dalam pemasaran adalah pedagang pengumpul, para penyalur/pedagang antar pulau, pedagang besar yang beroperasi di pusat-pusat besar, dan akhirnya para pengecer di daerah konsumsi itu sendiri yang berhadapan langsung dengan para konsumen.

Pada pemasaran kerajinan bambu masih sering dijumpai menempatkannya pedagang pengumpul desa sebagai tujuan utama dalam pemasaran hasil. Hanya sebagian kecil perajin yang langsung menjual hasil produksinya ke pedagang besar. Menurut Agustian (2005) dalam hal tujuan pemasaran ini, tampaknya orientasi dalam penjualan hasil lebih mengarah pada kelembagaan pemasaran yang paling dekat dan mudah dijangkau

JPPM ISSN: 2549 - 8347 (Online) ISSN: 2579 - 9126 (Print) Vol. 2 No. 2 September 2018 
perajin. Bahkan semakin berkembangnya kelembagaan pemasaran seperti halnya munculnya supplier dan dan pasar modern tidak dapat terakses langsung oleh para perajin karena berbagai kendala baik yang menyangkut kontinuitas, jumlah yang diminta, sistem pembayaran maupun kualitas barang yang diminta sangat ketat. Rantai pemasaran yang cukup panjang dapat menyebabkan tidak efisiennya sistem pemasaran. Oleh karena itu, terjadinya peningkatan produksi kerajinan bambu bila tidak diiringi dengan perbaikan dalam hal pemasarannya, maka sub sistem pemasaran selamanya dihadapkan dalam ketidakefisienan dan seringkali pihak perajin sebagai produsen memperoleh bagian harga yang kurang memadai bagi peningkatan usahanya.

Pengembangan sektor pertanian dalam arti luas harus diarahkan kepada sistem agribisnis dan agroindustri, karena pendekatan ini akan dapat meningkatkan nilai tambah sektor pertanian yang pada hakikatnya dapat meningkatkan pendapatan bagi pelaku-pelaku agribisnis dan agroindustri di daerah. Untuk mewujudkan tujuan pengembangan ekonomi kerakyatan, terutama di sektor pertanian maka perlu dipersiapkan kebijakan strategis untuk memperbesar atau mempercepat pertumbuhan sektor pertanian, khususnya peningkatan pendapatan dan kesejahteraan masyarakat. Salah satu cara untuk mencapai tujuan tersebut adalah pengembangan agribisnis dan agroindustri yang terencana dengan baik dan terkait dengan pembangunan sektor ekonomi lainnya. Lebih lanjut diungkapkan Suyono (2007) dalam Syahza (2007), upaya pemberdayaan ekonomi masyarakat pedesaan, sektor pertanian harus menjadi sasaran utama.Sektor ini harus dijadikan pijakan kokoh, sehingga di pedesaan dapat tercapai swasembada berbagai produk pertanian, terutama kerajinan tangan bambu, sebelum memasuki era perindustrian.Masalah pemasaran yang tak kalah pentingnya adalah rendahnya mutu sumberdaya manusia, khususnya di daerah pedesaan.Rendahnya kualitas sumberdaya manusia ini tidak pula didukung oleh fasilitas pelatihan yang memadai, sehingga penanganan produk mulai dari pra produksi sampai ke pasca produksi dan pemasaran tidak dilakukan dengan baik.Disamping itu, pembinaan perajin selama ini belum mengarah kepada praktik pemasaran. Maka dari itu tujuan dari kegiatan adalah memberdayakan kelompok masyarakat UMKM perajin bambu melalui pendidikan, dan pelatihan serta pendampingan dalam rangka meningkatkan pendapatan dan kesejahteraan.

\section{METODE KEGIATAN}

Kelompok masyarakat sasaran adalah UMKM perajin bambu Arrohman Desa Sirkandi Kecamatan Purwareja Klampok Kabupaten Banjarnegara. Pemilihan kelompok masyarakat perajin bambu tersebut didasarkan pada pertimbangan banyaknya potensi sumberdaya alam di daerah setempat terutama tanaman bambu yang potensinya dapat terus dimanfaatkan dan dikembangkan menjadi industri kreatif yang menjanjikan. Metode kegiatan yang dilakukan adalah pendidikan masyarakat melalui kegiatan penyuluhan tentang pengembangan industri kreatif, diversifikasi produk dan strategi pemasaran produk kerajinan bambu. Metode pelatihan berupa demonstrasi langsung atau praktik diversifikasi produk kerajinan bambu berupa piti dan tampah bambu. Pelatihan yang dipandu oleh narasumber (tenaga ahli) dan dibantu dengan seperangkat alat bantu untuk melakukan praktik secara langsung. Sebelum kegiatan pelatihan dilakukan terdapat beberapa hal kegiatan berupa persiapan yang perlu dilakukan.

\section{HASIL DAN PEMBAHASAN}

Hasil kegiatan yang telah dilaksanakan sesuai dengan tujuan yang telah ditetapkan dapat dijelaskan sebagai berikut : 


\section{Kegiatan Pendidikan Masyarakat}

Kegiatan pendidikan berupa penyuluhan tentang pengembangan industri kreatif berbasis potensi lokal. Dengan melihat potensi sumberdaya alam Desa Sirkandi terutama potensi jumlah tanaman bambu yang paling besar atau melimpah. Memiliki banyak peluang untuk dapat dikembangkan menjadi industri kreatif berbasis potensi desa. Apalagi didukung oleh keberadaan jumlah sumberdaya manusia yaitu para perajin bambu yang ada mencapai 107 orang. Pada kegiatan tersebut para perajin bambu juga diberikan pemahaman dan penjelasan tentang pengembangan industri kreatif bambu. Berdasarkan hasil assessment lapangan mengenai kondisi masyarakat akan ketersediaan kegiatan pengolahan potensi sumber daya alam, hasil yang diperoleh bahwa masyarakat belum memiliki kesadaran akan pentingnya pengolahan hasil komoditi sumber daya alam yang mulai diperhatikan pula oleh pemerintah. Dalam hal ini, diketahui bahwa jumlah pengrajin bambu masih menjalankan aktivitas tradisionalnya dengan produk kerajinan bambu. Hal ini juga didukung penjelasan dari Departemen Perdagangan, (2008) yang menyatakan bahwa ada beberapa arah dari pengembangan industri kreatif ini, seperti pengembangan yang lebih menitikberatkan pada industri berbasis: (a) lapangan usaha kreatif dan budaya (creative cultural industry); (b) lapangan usaha kreatif (creative industry), atau (c) Hak Kekayaan Intelektual seperti hak cipta (copyright industry).

Pada kegiatan penyuluhan tersebut juga diperoleh informasi bahwa kualitas produk kerajinan bambu yang dihasil oleh perajin masih rendah. Oleh karena itu kegiatan perlu dilanjutkan dengan kegiatan pendampingan dan pelatihan secara

berkelanjutan agar diperoleh kualitas produk yang baik. Hal tersebut senada dengan penjelasanan yang disampaikan oleh Wibhawa Tabel 1. Penerapan Strategi Bauran Pemasaran Produk Piti Bambu dkk (2017) bahwa pengelolaan komoditi sumber daya alam bambu masih belum optimal dilaksanakan oleh masyarakat mengingat proses produksi dan pemasaran kerajinan bambu belum berbentuk inovasi produk dan bernilai ekonomi rendah. Bila kuantitas sumber daya manusia dan sumber daya alam bambu meningkat namun belum disertai dengan pengelolaan yang baik, maka akan berdampak terhadap kurangnya kualitas produk kerajinan bambu yang berkesinambungan memberikan dampak terhadap kemajuan sosial ekonomi masyarakat.

Kegiatan pendidikan berupa penyuluhan juga dilakukan berkaitan dengan bagaimana upaya pengembangan strategi pemasaran produk kerajinan bambu terutama piti dan produk bambu lainnya. Seperti halnya yang disampaikan oleh Hermawan (2015) bahwa sebagai strategi bisnis, marketing merupakan tindakan penyesuaian suatu organisasi yang berorientasi pasar dalam menghadapi kenyataan bisnis, baik dalam lingkungan mikro maupun lingkungan makro yang terus berubah. Prosespemasaran diharapkan dapat menciptakan nilai untuk pelanggan dan membangun hubungan pelanggan.Salah satu strategi yang berhubungan dengan kegiatan pemasaran perusahaan adalah marketing mix strategy yang didefinisikan oleh Kotler dan Armstrong (1997) dalam Diniaty dan Agusrinal (2014) yang menyatakan bahwa marketing mix as the set of controllable marketing variables that the firm bleads to produce the response it wants in the target market. Strategi bauran pemasaran (Marketting Mix) meliputi straegi 4 P, yaitu strategi produk (product strategy), strategi harga (price strategy), strategi tempat (place strategy), dan strategi promosi (promotion strategy). 
Sarno

Pemberdayaan Kelompok Masyarakat Perajin Bambu Di Desa Sirkandi Purwareja Klampok Banjarnegara

\begin{tabular}{cll}
\hline No & Penerapan Strategi & Uraian/Keterangan \\
\hline 01 & $\begin{array}{l}\text { Strategi Produk } \\
\text { (Product Strategy) }\end{array}$ & $\begin{array}{l}\text { a. Produk piti bambu yang dipasarkanberukuran kecil } \\
\text { b. Produk piti bambu ukuran kurang lebih } 20 \mathrm{x} 20 \mathrm{x} \mathrm{cm} \\
\text { c. Produk ketebalannya/ketinggiannya sekitar } 5 \mathrm{~cm}\end{array}$ \\
02 & $\begin{array}{l}\text { Strategi Harga } \\
\text { (Price Strategy) }\end{array}$ & $\begin{array}{l}\text { a. Harga produk berkisar antara Rp } 250-\mathrm{Rp} 300 / \mathrm{buah} \\
\text { b. Harga produk biasa mengalami perubahan ketika menjelang hari } \\
\text { raya/lebaran dan hari besar tertentu }\end{array}$ \\
03 & $\begin{array}{l}\text { Strategi Tempat } \\
\text { (Place Strategy) }\end{array}$ & $\begin{array}{l}\text { a. Tempat pemasaran pada kios/warung,agen/distributor/pedagang besar } \\
\text { diluar kota, agen pengecer di pasar tradisional }\end{array}$ \\
04 & $\begin{array}{l}\text { Strategi Promosi } \\
\text { (Promotion Strategy) }\end{array}$ & $\begin{array}{l}\text { b. Ppaya dapat menembus pasar di luar wilayah } \\
\text { internet melal brosur/leaflet yang disebar dan melalui media }\end{array}$ \\
\hline
\end{tabular}

Sumber : data primer diolah, 2017

Kelompok masyarakat UMKM perajin bambu Arrohman Desa Sirkandi belum melakukan inovasi dan diversifikasi produk kerajinan bambu yang dilakukan dan pemasarannya masih bersifat terbatas. Keterampilan dan kapasitas para perajin dalam mengolah dan memanfaatkan bahan bambu juga masih terbatas. Oleh karena itu, kegiatan pelatihan bagi para perajin bambu dalam diversifikasi dan menciptakan inovasi produk kerajinan bambu yang kreatif sangat baik mengingat peluang kemajuan sosial ekonomi masyarakat Desa Sirkandi yang sedang berkembang. Menurut Wibhawa dkk (2017) bahwa adapun peluang dan potensi yang dapat ditinjau terhadap pemberdayaan perajin bambu untuk pengelolaan dan pemasaran produk kerajinan bambu diantaranya adalah diadakan sosialisasi terkait dengan informasi mengenai keuntungan dan manfaat dari pengelolaan produk kerajinan bambu sebagai salah satu inovasi industri rumah tangga kreatif yang bernilai. Hal ini juga dapat didukung dengan pengetahuan akan bagaimana pengelolaan bambu dapat berdampak terhadap kemajuan perekonomian dan diperkuat bila diadakannya kerjasama antar kelompok perajin bambu dalam sebuah wadah koperasi bersama.

\section{Kegiatan Pelatihan Diversifikasi Produk dan Penerapan Standarisasi Tahapan} Produksi

Kegiatan pelatihan diversifikasi perajin bambu Desa Sirkandi. Pelatihan diversifikasi produk tersebut juga dibarengi dengan pelatihan penerapan standarisasi pada tahapan produksi kerajinan bambu. Produk hasil pelatihan diversifikasi adalah produk kerajinan berupa tampah atau nampan bambu. Selama ini perajin hanya memproduksi kerajinan jenis piti bambu saja. Seperti diketahui bahwa piti bambu memiliki nilai jual yang lebih murah dibandingkan dengan produk tampah bambu.

Adapun pelatihan diversifikasi produk juga dibarengi dengan pelatihan penerapan standart operational procedure(SOP) dan standart sanitation operational procedure (SSOP) pada tahapan proses produksi piti bambu, penerapan standar pengawasan mutu produk, dan diversifikasi serta inovasi produk kerajinan bambu berupa tampah bambu. Kegiatan pelatihan jugadidampingi oleh kelompok perajin tampah bambu dari daerah lain yaitu daerah Desa Situwangi Kecamatan Rakit Kabupaten Banjarnegara yang merupakan sentra kerajinan bambu. Pelatihan ini ditujukan untuk memberi keterampilan kepada perajin bambu dalam pengembangan industri kreatif bambu di Desa Sirkandi.Deskripsi produk kerajinan bambu hasil kegiatan pelatihan para perajin bambu Desa Sirkandi, dan hasil penerapan standart operational procedure (SOP) dan standart sanitation operational procedure (SSOP) pada tahapan proses produksi tersaji pada Tabel 2 . produk kerajinan bambu ditujukan bagi para 
Sarno

Pemberdayaan Kelompok Masyarakat Perajin Bambu Di Desa Sirkandi Purwareja Klampok Banjarnegara

Tabel 2. Deskripsi Produk Kerajinan Bambu

\begin{tabular}{|c|c|c|c|}
\hline \multirow{2}{*}{ No } & \multirow{2}{*}{ Deskriptor } & \multicolumn{2}{|c|}{ Varian } \\
\hline & & Anyam 8 & Anyam 9 \\
\hline A & Deskripsi Produk Piti Bambu & & \\
\hline 1 & Deskripsi umum & $\begin{array}{l}\text { Wadah yang terbuat dari anyaman bamt } \\
\text { bagian alas dan tutup }\end{array}$ & berbentuk balok, terdiri dari \\
\hline 2 & Warna & Coklat khas bambu (tanpa pewarna) & \\
\hline 3 & Ukuran & $10 \times 10 \times 6 \mathrm{~cm}$ & $12 \times 12 \times 7 \mathrm{~cm}$ \\
\hline 4 & Penggunaan & Wadah getuk goreng (kemasan $250 \mathrm{~g}$ ) & $\begin{array}{l}\text { Wadah getuk goreng (kemasan } \\
500 \mathrm{~g} \text { ) }\end{array}$ \\
\hline $\mathrm{B}$ & Deskripsi Produk Tampah Ban & & \\
\hline 1 & Deskripsi umum & $\begin{array}{l}\text { Alat bantu yang terbuat dari anyaman b } \\
\text { maupun biji-bijian, dari bahan lain yang }\end{array}$ & $\begin{array}{l}\text { nbu untuk memisahkan beras, } \\
\text { idak dikendaki (Jawa: menampi) }\end{array}$ \\
\hline 2 & Warna & Coklat khas bambu (tanpa pewarna) & \\
\hline 3 & Ukuran & $\varnothing 50 \mathrm{~cm}$ & \\
\hline 4 & Penggunaan & Menampi beras/bijian, menjemur bahan & angan \\
\hline
\end{tabular}

Tahapan produksi piti dan tampah bambu memiliki persamaan dalam hal bahan baku yang digunakan. Bahan baku yang digunakan untuk kedua produk tersebut adalah bambu tali. Morfologis bambu tali yaitu warna batang bambu tali adalah hijau sampaikekuning-kuningan. Batang bambu tali tidak bercabang di bagian bawah. Diameter batang antara 2,5 sampai $15 \mathrm{~cm}$, tebal dinding 3 sampai $15 \mathrm{~mm}$, danpanjang ruas atau buluhnya 45 sampai $65 \mathrm{~cm}$. Bentuk batang bambu tali sangat teratur. Bambu tali digunakan sebagai bahan baku karena sifatnya yangliat dan tidak mudah putus atau patah. Selain itu, serat bambunya juga lebih halus dan lebih mudah untuk dianyam. Bambu tali yang digunakan sebagai bahan baku telah berumur 6 bulan dengan diameter 7-10 $\mathrm{cm}$. Sebelum diolah lebih lanjut, bambu tali yang telah dipotong akan dijemur terlebih dahulu selama \pm 4 hari.

Tabel 3. Standarisasi Tahapan Produksi Piti dan Tampah Bambu

\begin{tabular}{cll}
\hline No & \multicolumn{1}{c}{ Tahapan Proses } & \multicolumn{1}{c}{ Standarisasi } \\
\hline A & Standarisasi Tahapan Produksi Piti Bambu & \\
\hline 1 & Pengadaan bambu & Bambu tali \\
2 & Pemotongan bambu & $50 \mathrm{~cm}$ dan $35 \mathrm{~cm}$ \\
3 & Pembelahan bambu & 1 bilah bambu dibelah menjadi 8-10 bagian \\
4 & Pembentukan lapisan tipis bambu & $\begin{array}{l}\text { Lapisan tipis bambu diirat hingga ketebalan } 0,4-0,5 \\
\text { mm }\end{array}$ \\
& & Dianyam rapat dan rapi \\
5 & Penganyaman dan pembentukan struktur & Dirapikan pada sisi terluar anyaman \\
6 & Perapian piti bambu & \\
\hline B & Standarisasi Tahapan Produksi Tampah Bambu & Bambu tali \\
\hline 1 & Pengadaan bambu & 55 cm dan 50 cm \\
2 & Pemotongan bambu & 1 bilah bambu dibelah menjadi 8-10 bagian \\
3 & Pembelahan bambu & Lapisan tipis bambu diirat hingga ketebalan 0,7-0,8 \\
4 & Pembentukan lapisan tipis bambu & mm \\
5 & Penganyaman dan pembentukan tampah & Dianyam rapat dan rapi \\
6 & Pemberian pegangan tampah & Pegangan tampah yang dibentuk dari 2 bilah bambu
\end{tabular}




\begin{tabular}{lll}
\hline & & terlihat rapi dan kokoh \\
& Penghilangan sisa serabut bambu dengan pemanasan & $\begin{array}{l}\text { Sisa-sisa serabut halus bambu hilang dan terbentuk } \\
\text { warna kecoklatan yang khas }\end{array}$ \\
8 & Pengikatan pegangan & Pengikatan dilakukan dengan rapi dan kuat \\
\hline
\end{tabular}

Melihat nilai historis dan budaya lokal kerajinan bambu yang sangat berharga, maka dinilai perlu melakukan langkah-langkah strategis guna tetap melestarikan Desa Sirkandi sebagai daerah sentra kerajinan bambu dengan tetap memperhatikan aspek peningkatan kesejahteraan masyarakat dan permintaan pasar akan kerajinan bambu. Langkah yang dinilai tepat guna mengatasi kondisi tersebut adalah dengan meningkatkan kuantitas dan kualitas produk kerajinan bambu di Desa Sirkandi. Peningkatan kuantitas, baik dalam hal jumlah produksi maupun keberagaman produk yang dihasilkan akan semakin memperbesar peluang pasar dan menjamin tersedianya produk dalam jumlah tertentu secara kontinyu sebagaimana permintaan pasar. Sementara itu peningkatan kualitas, melalui adanya standarisasi produk sesuai regulasi dan permintaan pasar, diharapkan akan memberikan jaminan kepuasan konsumen terhadap produk kerajinan bambu yang diproduksi.

\section{Kegiatan Pelatihan Penerapan Strategi Bauran Pemasaran Produk}

Kegiatan pelatihan penerapan strategi bauran pemasaran produk secara sederhana yang dilakukan pada para perajin bambu membawa manfaat terhadap adanya peningkatan pengetahuan dan kemampuan para perajin merumuskan dan membuat strategi pemasaran untuk produk piti dan tampah bambu yang mereka produksi. Menurut Selang (2013) menyatakan bahwa bauran pemasaran merupakan salah satu strategi pemasaran untuk menyampaikan informasi secara luas, memperkenalkan suatu produk barang dan jasa, merangsang konsumen untuk memberi bahkan menciptakanpreferensi pribadi terhadap image suatu produk. Oleh karena itu bauran pemasaran dianggap sebagai salah satuunsur strategi yang paling potensial di dalam memasarkan produk.

Merujuk pada hasil kegiatan yang telah dilakukan maka diperlukan langkah rencana tindak lanjut. Rencana tindak lanjut yang diperlukan antara lain adalah kegiatan pendampingan secara berkelanjutan kepada para perajin bambu dalam upaya pemasaran produk, penguatan kelembagaan yang terlibat dalam pemasaran produk, pengembangan sinergitas kelompok perajin bambu dengan pihak pemerintah atau pun perusahaan swasta. Pendampingan para perajin bambu dalam mengembangkan industri kreatif berbasis potensi lokal desa

\section{SIMPULAN}

Berdasarkan pada hasil kegiatan yang telah dilakukan maka dapat disimpulkan bahwa kegiatan pemberdayaan kelompok masyarakat UMKM perajin bambu di Desa Sirkandi memberikan manfaat berupa peningkatan pengetahuan dan kapasitas, semakin termotivasi serta para perajin bambu paham tentang pemanfaatan potensi bambu sebagai bahan kerajinan dalam mendukung kemandirian dan keberlanjutan usaha menuju pengembangan industri kreatif berbasis potensi desa. Selain itu memberikan manfaat adanya peningkatan keterampilan usaha melalui penerapan strategi diversifikasi dan pemasaran produk kerajinan bambu.

\section{DAFTAR PUSTAKA}

Agustian, A, (2005). Analisis Berbagai Bentuk Kelembagaan Pemasaran dan Dampaknya Terhadap Peningkatan 
Sarno

Pemberdayaan Kelompok Masyarakat Perajin Bambu Di Desa Sirkandi Purwareja Klampok Banjarnegara

Usaha Komoditas Pertanian. Pusat Penelitian dan Pengembangan Sosial Ekonomi. Badan Penelitian dan Pengembangan. Departemen Pertanian.

Ardiansyah, (2011). Peluang Usaha dari Kerajinan Bambu. STMIK Amikom Yogyakarta.

BAPPENAS, (2011), Masterplan Percepatan dan Perluasan Pembangunan Ekonomi Indonesia.

BPS Kab. Banjarnegara. 2017. Kecamatan Purwareja Klampok Dalam Angka 2017.

http://banjarnegarakab.bps.go.id.Diaks es 09 Februari 2018.

Departemen Perdagangan RI, (2008), Pengembangan Ekonomi Kreatif Indonesia 2025: Rencana Pengembangan Ekonomi Kreatif Indonesia 2009 - 2015.

Diniaty, D, Agusrinal. (2014). Perancangan Strategi Pemasaran Pada Produk Anyaman Pandan. Jurnal Sains, Teknologi dan Industri, 11, (2), 175 184.

Hermawan, H, (2015). Analisis Pengaruh Bauran Pemasaran Terhadap Keputusan, Kepuasan dan Loyalitas Konsumen Dalam Pembelian Roti Ceria di Jember. Jurnal Manajemen dan Bisnis Indonesia, 1, (2) .

Sarno, Lukmanul H, Bondan HS. (2014). IbM Kerajinan Bambu di Purwareja Klampok Banjarnegara. Laporan Mono Tahun Kegiatan Pengabdian Kepada Masyarakat. Politeknik Banjarnegara.
Berbasis Agribisnis di Daerah Riau, Lembaga Penelitian Universitas Riau, Pekanbaru.

Selang, C.A.D., (2013). Bauran Pemasaran (Marketing Mix) Pengaruhnya TerhadapLoyalitas Konsumen Pada Fresh Mart Bahu Mall Manado. Jurnal EMBA, 1, (3). 71-80.

Wibhawa, B, Sahadi H, Agus WR, Budi M.T, Maulana Binahayati.2017. Pengembangan Produktivitas Pengrajin Bambu Melalui Pelatihan Olahan Aneka Kerajinan Bambu di Desa Genteng Kecamatan Sukasari Sumedang. Jurnal Penelitian \& PPM. 4, (2), $129-389$.

Syahza. A, (2007). Model Pemberdayaan Masyarakat Dalam Upaya Percepatan Pembangunan Ekonomi Pedesaan 